\title{
Enumeration, Isolation and Antibiotic Susceptibility Profile of Bacteria Associated With Mobile Cellphones in a University Environment
}

\author{
${ }^{*}$ A.H. Kawo and A.M. Musa \\ 1Department of Microbiology, Faculty of Science, Bayero University, PMB 3011, Kano, Nigeria \\ [Corresponding author: Email; ahkawo@yahoo.com; 留: +2348023153895]
}

\begin{abstract}
A study was carried out between February and March, 2012, to enumerate, isolate and identify bacteria associated with mobile cell phones in a University environment. This was with a view to determining the bacterial load and their susceptibility pattern to some commonly-used antibiotics. Samples were collected from mobile cell phones of staff, marketers and students in Bayero University, Kano, Nigeria using aseptic swab technique. A total of thirty-five (35) mobile phones were randomly sampled from the following study groups: 10 University staff, 12 marketers and 13 students. For each mobile phone, two sterile swabs moistened with normal saline were rotated over the surface of both sides of the mobile phone and soaked in $10 \mathrm{ml}$ peptone water. Enumeration of the bacterial counts was carried out using pour-plate technique while the bacterial isolates were identified using cultural, morphological and biochemical techniques. The results showed that marketers, students and University staff had the overall mean aerobic mesophilic bacterial counts of $5.25 \times 10^{2}, 4.48 \times 10^{2}$ and $2.50 \times$ $10^{2} \mathrm{cfu} / \mathrm{ml}$ respectively. Twenty-eight bacterial isolates belonging to four genera: Escherichia coli $7(25.0 \%)$ Staphylococcus aureus 15(53.6\%), Salmonella species 2(7.1\%) and Klebsiella species 4(14.3\%) were identified. Generally, S. aureus was the most isolated with 15(53.6\%) while the least was Salmonella species with only 2(7.1\%). Antibiotic susceptibility testing of the isolates indicated that $S$. aureus species had the highest susceptibility of 14(93.3\%) against cipfloxacin while Salmonella species had 1(50.0\%) against augmentin whereas Klebsiella species had 1(25.0\%) each against gentamycin and streptomycin. On the other hand, Salmonella species was not susceptible to gentamycin, perfloxacin and streptomycin each with $0(0.0 \%)$. Overall susceptibility was highest against ciprofloxacin with 24(85.7\%) while the least was recorded against gentamycin with 6(21.4\%). The identified bacteria have pathogenic potential and hence their presence on the cell phones surfaces could serve as a source of cross-transmission of bacterial infections in the University community and its environs.
\end{abstract}

Keywords: Bacteria, Contamination, Cell phones, Susceptibility profile, Antibiotics, University.

\section{INTRODUCTION}

The global system for mobile telecommunication (GSM) was established in 1982 in Europe with a view to providing and improving communications networks (Naubauer et al., 2005). Today, mobile phones have become one of the most indispensable accessories of professional and social life. Although they are usually stored in bags or pockets, mobile phones are handled frequently and held to the face (Yusha'u et al., 2008; 2010). The constant handling of the mobile phones by users makes it a breeding place for transmission of microorganisms as well as hospital-associated infections (Glodblatt et al., 2007; Yusha'u et al., 2010). Growing evidences have indicated that contaminated fornites or surfaces play a key role in the spread of bacterial infections (Kawo and Rogo, 2008; Kawo et al., 2009; 2012; Enemuor et al., 2012a; b). The first study of bacterial contamination of mobile phones was conducted in a teaching hospital in Turkey with bed capacity of 200 and one intensive care unit (Karabay et al., 2007). Another study on mobile phones in New York has shown that the examined phones were found to harbor pathogenic microorganisms (Goldblatt et al., 2007). In Nigeria, the usage of cell phones has increased to more than forty million with more than eight service providers (Nwadike, 2007). Cell phones have been identified as one of the carriers of bacterial pathogens (Mbata, 2003; Austin. et al., 2006; Akinyemi et al., 2009; Yusha'u et al., 2010). The present study was aimed at investigating the bacterial contamination of mobile phones of students, marketers and staff in Bayero University old campus, Kano, Nigeria and their susceptibility profile to some commercially-available antibiotics.

\section{MATERIALS AND METHODS}

\section{Study area/population and sample collection}

The study was conducted in Bayero University, old campus, Kano State, northern Nigeria between February and March, 2012. A total of thirty-five (35) mobile phones were randomly sampled from the following study groups: 10 University staff, 12 
marketers and 13 students. A sterile cotton swab stick was soaked in sterile peptone water to moisten it. The target phone was swabbed over its surface after which the swab stick was put quickly into its container and sealed. The cotton end was aseptically cut off and soaked in $10 \mathrm{ml}$ of peptone water labeled with the specimen number and incubated at $37 \pm 0.5^{\circ} \mathrm{C}$ for 24 hours. This served as the stock culture. Same technique was employed for each of the samples (Chesebrough, 2000).

\section{Enumeration of aerobic, mesophilic bacterial counts}

Aerobic, mesophilic bacterial count was determined using serial dilution technique (Chesebrough, 2000). From the stock culture in the peptone water medium (above), $1.0 \mathrm{ml}$ of the sample was aseptically pipetted into a sterile test tube containing $9.0 \mathrm{ml}$ of peptone water. The contents were mixed thoroughly. A quantity $(1.0 \mathrm{ml})$ of the dilution from each of the test tubes $\left(10^{-1}\right.$. $\left.-10^{-3}\right)$ was aseptically pipetted and transferred into correspondingly-labeled Petri dishes in duplicates. This was followed by pouring of prepared, cooled but molten nutrient agar (oxoid) medium onto the plates. The contents were gently swirled and allowed to solidify at room temperature. Finally, the plates were aerobically incubated at $37 \pm 0.5^{\circ} \mathrm{C}$ for 24 hours. The colonies developed after the incubation period were counted and the mean count obtained was recorded and expressed in colony forming unit per milliliter (cfu/ml) of the sample analyzed.

\section{Cultural, morphological and biochemical characterization of the bacterial isolates}

Loopful of discrete colonies on nutrient agar (oxoid) medium were selected and aseptically sub-cultured onto selective and differential media (blood agar, MacConkey agar, EMB agar and mannitol salt agar media). The inoculated plates were incubated at $37 \pm 0.5^{\circ} \mathrm{C}$ for 24 hours after which their cultural characteristics were observed and recorded. Discrete suspected colonies were further subjected to Gram's staining to characterize their morphology while biochemical tests (catalase, coagulase, citrate, indole, oxidase, urease, TSI, MR-VP and motility) were carried out to authenticate their identity (Chesebrough, 2000).

\section{Antibiotic sensitivity discs}

The antibiotics used in this study were commerciallyprepared, purchased from Sabon-gari market in the metropolitan city of Kano, Nigeria. They included augmentin $(3 \mu \mathrm{g})$, gentamycin $(10 \mu \mathrm{g})$, amoxicillin $(2 \mathrm{~S}$ $\mu g)$, perfloxacin $(5 \mu g)$, ciprofloxacin $(5 \mu g)$ and streptomycin $(3 \mu \mathrm{g})$.

\section{Standardization of the inoculum and antibiotic susceptibility testing of the isolates}

The standardization of the inoculum was done according to the method of Chesebrough (2000) while the antibiotic susceptibility testing was carried out using disc-diffusion technique (Kirby-Bauer, 1996). Here, a loopful of a bacterial colony was picked and emulsified in a Bijou bottle containing $3.0 \mathrm{ml}$ of normal saline. The turbidity was adjusted to the turbidity of barium sulphate (0.5McFarland standard). A cotton swab was dipped into the suspension and the swab was pressed against the side of the bottle to remove excess fluid. The inoculated swab was then streaked across the surface of nutrient agar and allowed to dry for five minutes after which sterile forceps were used to carefully remove the disc from its pack and gently pressed onto the agar surface. The plates were finally incubated at $37^{\circ} \mathrm{C}$ for 24 hours. After the incubation period, the diameter of zone of inhibition (clearance) was measured using a millimeter rule from the center of the disc to the edge of the circumference of the clearance zone and recorded to the nearest millimeter. The results were recorded and interpreted on the basis of Clinical and Laboratory Standards Institute guidelines (CSLI, 2005).

\section{RESULTS}

Table 1 shows the overall mean aerobic, mesophilic bacterial counts and the distribution of the bacterial isolates according to the sample sources. Marketers, students and University staff had the overall mean aerobic, mesophilic bacterial counts of $5.25 \times 10^{2}, 4.48$ $\times 10^{2}$ and $2.50 \times 10^{2} \mathrm{cfu} / \mathrm{ml}$ respectively. Morphological and biochemical characteristics of the bacterial isolates are shown in Table 2, which indicated the recovery of 28 isolates comprising of four genera of $E$. coli $7(25.0 \%)$, S. aureus $15(53.6 \%)$, Salmonella species 2(7.1\%) and Klebsiella species 4(14.3\%). Results for the antibiotic susceptibility testing of the isolates (Table 3 ) indicated that $S$. aureus species had the highest sensitivity of 14(93.3\%) against cipfloxacin while Salmonella species had 1(50.0\%) against augmentin whereas Klebsiella species had 1(25.0\%) each against gentamycin and streptomycin. On the other hand, Salmonella species was not susceptible to gentamycin, perfloxacin and streptomycin each with 0(0.0\%). Overall susceptibility was highest in ciprofloxacin with 24(85.7\%) while the least was recorded against gentamycin with 6(21.4\%). In addition, the results 
(Table 3) show that generally, the bacterial isolates were moderately susceptible to amoxicillin and streptomycin with 13(46.4\%) each while higher susceptibility was obtained against perfloxacin and ciprofloxacin with $23(82.1 \%)$ and 24(85.7\%) respectively.

\section{DISCUSSION}

The results of the present study (Table 1) showed that marketers had the highest contamination of bacterial agents with 12(100.0\%) followed by the University staff with $7(70.0 \%)$ while students had the lowest of 9(69.2\%). The overall mean aerobic, mesophilic bacterial counts of $5.25 \times 10^{2}, 4.48 \times 10^{2}$ and $2.50 \times 10^{2}$ $\mathrm{cfu} / \mathrm{ml}$ were also recovered from the marketers, students and University staff respectively. The high prevalence of bacteria isolated from mobile phones of the marketers might be as a result of multiple usages and/or long-time exposure to environment especially those handling raw vegetables and meat (Akinyemi et al., 2009; Famurewa and David, 2009). The frequency of use and exposure of mobile phones to environmental surfaces including the hands and skins of users could have also determined the degree of contamination of these phones (Mohammed et al., 2006). Similarly, poor handling, among other factors, might account for the high level of the bacterial load in the phones of the marketers compared to the students and University staff. In addition, improved personal hygiene generally observed among the students and university staff could be the reason for this observation (Akinyemi et al., 2009). Brady et al (2006) had documented that combination of constant handling and heat generation provides a favorable breeding ground for microbes that are normally found on our skin. Generally, all the sampled groups had viable counts lower than $10^{6}$ $\mathrm{cfu} / \mathrm{ml}$ (Table 1). This is therefore within WHO (1980) accepted limit for microbial contamination for any surface sample. WHO (1980) reported that contact surfaces should not exceed $1.20 \times 10^{6} \mathrm{cfu} / \mathrm{ml}$. The results obtained in this study are however, contrary to the findings of Yusha'u et al (2010) who reported a gross contamination rate of both commercial and personal mobile phones in some locations within Kano metropolis. The variation in sample size could have been the reason for this observation. Staphylococcus aureus was the most prevalent bacterial agent isolated with $15(53.3 \%)$ of all the mobile phones of the study subjects evaluated. This corresponds with the findings of Famurewa and David (2009) in which S. aureus was the most frequently encountered bacterial agent isolated from $32.9 \%$ of the samples evaluated. Akinyemi et al (2009) have documented that this may be because this type of bacterium increases in optimum temperature as phones are kept warm in pockets, handbags and brief cases. In addition, the high occurrence rate of $S$. aureus could be traced to the fact that it is abundant in human body especially as a normal flora of the skin. It is also reported to contribute 40-50\% nasal carriers in humans (Uabol-Egbenni, 2003). On the other hand, the low occurrence of Klebsiella species might be associated with the fact that this bacterium is present in the respiratory tract and faeces of about $5 \%$ normal individuals (Chesebrough, 2000). The occurrence of Salmonella species, though recovered in low numbers from only the marketers and students, and being potential pathogens, could have been as a result of community-acquired infections (Togoe et al., 2011). Thus, these organisms could have come in contact with the cell phones through soil, clothing, food and/or hands of the users (UabolEgbenni, 2003). The organisms recovered in the present study are all potential disease-causing agents. For example, S. aureus could elaborate toxins in foods, which are dangerous to human and other animal health (Ogbini and Omu, 1986). Thus, it has been known to be responsible for food intoxication and poisoning (Wieneke et al., 1993) while Salmonella and Klebsiella species are variously responsible for intestinal and respiratory infections, enteritis and stomach disorders (Garba, 2002). The roles of these organisms in both nosocomial and community-acquired infections have been well documented (Akinyemi et al., 2007; 2009; Brady et al., 2006; Borer et al., 2005; Glodblatt et al., 2007; Hota, 2004). The frequent handling of both the mobile and money could also make it easy for cross contamination (Kawo et al., 2009; Yusha'u et al., 2010). On the overall, the total resistance of the Salmonella species against some of the tested antibiotics (gentamycin, perfloxacin and streptomycin) and the low susceptibility of the isolates generally to gentamycin (Table 3) could be attributed to common use of these antibiotics as observed in previous studies presenting public health problems (Tagoe et al., 2011). In addition, gross misuse of these antibiotics in chemotherapy especially in this part of the country could explain the reason for this observation as earlier reported by Kumurya et al (2010). 
Kawo and Musa: Enumeration, Isolation and Antibiotic Susceptibility Profile of Bacteria Associated With Mobile.........

Table 1: Overall mean aerobic, bacterial counts and distribution of the bacterial isolates according to the sample source

\begin{tabular}{|c|c|c|c|c|c|c|}
\hline \multirow[b]{2}{*}{$\begin{array}{l}\text { Sample } \\
\text { Source }\end{array}$} & \multirow[b]{2}{*}{$\begin{array}{l}\text { ** Number of } \\
\text { samples } \\
\text { collected }\end{array}$} & \multirow[b]{2}{*}{$\begin{array}{c}\text { Number of } \\
\text { positive } \\
\text { samples }\end{array}$} & \multicolumn{4}{|c|}{ *Bacteria isolated } \\
\hline & & & $\begin{array}{c}\text { Staphylococcus } \\
\text { aureus }\end{array}$ & $\begin{array}{c}\text { Klebsiella } \\
\text { species }\end{array}$ & $\begin{array}{c}\text { Salmonella } \\
\text { species }\end{array}$ & $\begin{array}{c}\text { Escherichia } \\
\text { coli }\end{array}$ \\
\hline Marketers & $\begin{array}{c}12(5.25 x \\
\left.10^{2}\right)\end{array}$ & $12(100.0)$ & $5(41.7)$ & $3(25.0)$ & $1(8.3)$ & $3(25.0)$ \\
\hline Staff & $\begin{array}{c}10(2.50 x \\
\left.10^{2}\right)\end{array}$ & $7(70.0)$ & $4(57.1)$ & $1(14.3)$ & ND & $2(28.6)$ \\
\hline Students & $\begin{array}{c}13(4.48 x \\
\left.10^{2}\right)\end{array}$ & $9(69.2)$ & $6(66.7)$ & ND & $1(11.1)$ & $2(22.2)$ \\
\hline Total & $35\left(4.08 \times 10^{2}\right)$ & $28(80.0)$ & $15(53.6)$ & $4(14.3)$ & $2(7.1)$ & $7(25.0)$ \\
\hline
\end{tabular}

${ }^{*}$ Values in brackets are percentages $\quad{ }^{* * F i g u r e s}$ in brackets are the overall mean bacterial counts in cfu/ml) $\quad \mathrm{ND}=$ Not detected

Table 2: Morphological and biochemical characteristics of the bacterial isolates

\begin{tabular}{|c|c|c|c|c|c|c|c|c|c|c|c|c|}
\hline $\begin{array}{l}\text { Gram's } \\
\text { reaction }\end{array}$ & Indole & MR & VP & Citrate & Catalase & Urease & Motility & Oxidase & Coagulase & TSI & $\begin{array}{l}\text { No. of } \\
\text { isolates }\end{array}$ & $\begin{array}{l}\text { Organism } \\
\text { identified }\end{array}$ \\
\hline $\begin{array}{c}\text { Gram- } \\
\text { negativ } \\
\text { e rods }\end{array}$ & + & + & - & - & NA & NA & NA & NA & NA & NA & 07 & E. coli \\
\hline $\begin{array}{l}\text { Gram- } \\
\text { positive } \\
\text { cocci }\end{array}$ & NA & NA & NA & NA & + & + & - & - & + & NA & 15 & S. aureus \\
\hline $\begin{array}{c}\text { Gram- } \\
\text { negativ } \\
\text { e rods }\end{array}$ & - & + & - & + & NA & - & + & NA & NA & NA & 02 & $\begin{array}{l}\text { Salmonella } \\
\text { species }\end{array}$ \\
\hline $\begin{array}{c}\text { Gram- } \\
\text { negativ } \\
\text { e rods }\end{array}$ & - & - & + & + & NA & + & - & NA & NA & + & 04 & $\begin{array}{c}\text { Klebsiella } \\
\text { species }\end{array}$ \\
\hline
\end{tabular}

Table 3: Antibiotic susceptibility profile of the bacterial isolates (figures in brackets are percentages)

\begin{tabular}{|c|c|c|c|c|c|c|c|}
\hline Bacterial Isolate & $\begin{array}{l}\text { Number } \\
\text { isolated }\end{array}$ & $\begin{array}{l}\text { GEN } \\
\mu \mathrm{g})\end{array}$ & AUG $(3 \mu \mathrm{g})$ & $\begin{array}{l}\text { AMX } \\
(25 \mu \mathrm{g})\end{array}$ & PFX $(5 \mu \mathrm{g})$ & СРX $(5 \mu \mathrm{g})$ & $\begin{array}{l}\text { STR } \\
(3 \mu \mathrm{g})\end{array}$ \\
\hline Escherichia coli & $7(25.0)$ & $2(28.6)$ & $4(57.1)$ & $1(10.0)$ & $7(100.0)$ & $5(71.4)$ & $2(28,6)$ \\
\hline Staph. aureus & $15(53.6)$ & $3(20.0)$ & $8(53.3)$ & $8(53.3)$ & $12(80.0)$ & $14(93.3)$ & $10(66.7)$ \\
\hline Salmonella spp. & $2(7.1)$ & $0(0.0)$ & $1(50.0)$ & $2(100.0)$ & $0(0.0)$ & $2(100.0)$ & $0(0.0)$ \\
\hline Klebsiella species & $4(14.3)$ & $1(25.0)$ & $4(100.0)$ & $3(75.0)$ & $4(100.0)$ & $3(75.0)$ & $1(25.0)$ \\
\hline Total & $28(100.0)$ & $6(21.4)$ & $17(60.7)$ & $13(46.4)$ & $23(82.1)$ & $24(85.7)$ & $13(46.4)$ \\
\hline
\end{tabular}




\section{CONCLUSION}

The study show that the mobile phones examined were loaded with large numbers of bacterial including potential disease-causing ones. The results therefore highlight the health implications of using other people's phones as they could be loaded with microorganisms capable of causing various diseases and infections. Thus, cell phones could serve as vehicles of diseases.

\section{RECOMMENDATIONS}

Since restriction or even prohibition of the use of GSM handsets such devices may prove impractical in a public setting, strategies for preventing disease transmission are needed, especially given the risk of continuing contamination through hand-to-cell phone contact. Such strategies should target behavior controls of GSM handsets users. In addition, the following should be considered:

a. Frequent hand cleansing, especially with instant hand sanitizers is the most significant step to help prevent faeco-oral and droplet transmissions.

b. The cell phones should be handled in a manner that does not get contaminated with dirt and/or disease-causing agents.

c. The cell phones should be regularly cleaned with relevant disinfectants.

d. Covering the mouth or nose when coughing or sneezing decreases droplet spread and makes hand cleansing even more important.

\section{REFERENCES}

Akinyemi, K.O, Barmiro, B.S. and Coker, A.O. (2007). Salmonellosis in Lagos, Nigeria: Incidence of Plasmodium falciparum associated co-infection, pattern of antimicrobial resistance and emergence of reduced susceptibility of fluroquinolones. Journal of Health, Population and Nursing, 25: 351-358.

Akinyemi, K.O., Audu, D.A., Olabisi, O.A. and Akintoye, O.C. (2009). The potential role of mobile phones in the spread of bacterial infections. Journal of Infectious Diseases, 3(8): 628-632.

Austin, D.J., Kristinsson, K..G. and Anderson, R.M. (2006). The relationship between the volume of antibacterial consumption in human communities and frequency of resistance. Journal of American Medical Information, 96: 1152-1156.

Brady, R.R., Wasson. A., String, I., Mc-Allister, C. and Damani, N.N. (2006). Is your phone bugged?: The incidence of bacteria known to cause nosocomial infection in health care workers mobile phones. Journal of Hospital Infections, 62:123125.

Borer, A., Rozalia, S. E., Nechama, P., Eytan, H., Ronit, T., Klaris, R. and Francis, S. (2005). Cell phones and Acinobacter transmission. Emerging Infectious Diseases, 11(1): 1160-1161.

Bures, S., Fish-Brain, J.T., Uyehana, C.F., Parker, J.M. and Berg, B.W. (2000). Computer keyboard and faucet handles as reservoirs of nosocomial pathogens in intensive care unit. American Journal of Infections and Control, 28: 446-471.

Chesebrough, M. (2000). Medical laboratory manual for tropical countries Volume 11. Second edition, University Press, Cambridge, Great Britain, 377pp.

Clinical and Laboratory Standards Institute (2005). Performance for antimicrobial susceptibility testing. Fifteenth Informational Supplement 3(1):100-515

Enemuor, S.C., Apeh, T.A. and Oguntibeju, O.O. (2012a). Microorganisms associated with computer keyboards and mice in a university environment. African Journal of Microbiology Research, 6(20): 4424-4426.

Enemuor, S.C., Victor, P.I. and Oguntibeju, O.O. (2012b). Microbial contamination of currency counting machines and counting room environments in selected commercial banks. Scientific Research and Essays, 7(14): 15081511.

Famurewa, O. and David, O.M. (2009). Cell phones: A medium of transmission of bacterial pathogens. World Rural Observations, 1(2): 69-72.

Garba, C. (2002). Attachment of Staphylococcus aureus to different plastic tubes in-vitro. Journal of Medical Microbiology, 40(1): 37-42.

Glodblatt, J.G., Krief, I., Haller, T.D., Milloul, V. SixSmith, D.M., Srugo, I. and Potasman, I. (2007). Use of cellular telephones and transmission of pathogens by medical staff in New York and Israel. Infections Control of Hospital and Epidemiology, 28: 500-503.

Hassan, A.N., Birt, D.M. and Frank, J.F. (2004). Behavior of Listeria monocytogens in a Pseudomonas putida biofilm on a condensable forming surface. Journal of Food Protection, 67(2): 322-327.

Hota, B. (2004). Contamination, disinfection and cross colonization of hospital surface reservoirs for 
nosocomial infections. Clinical Infectious Diseases, 39: 1182-1189.

Isaacs, D.Y., Daley, A. and Dalton, D. (1998). Swabbing computer in search of nosocomial bacteria. Journal of Pediatrics Infectious Diseases, 17: 533.

Karabay, O., Kocoglu, E. and Tahtaci, M. (2007). The role of mobile phones in the spread of bacteria associated with nosolomial infections. Journal of Infectious Diseases in Developing Countries, 1: 72-73.

Kawo, A.H. and Rogo, L.D. (2008). Health implications of the bacterial load of computer keyboards International Journal of Agricultural Science, Science, Engineering and Technology, Series B, 7(2): 1155-120.

Kawo, A.H., Adam, M.S., Abdullahi, B.A. and Sani. M.N. (2009). Prevalence and public health implications of the microbial load of abused naira notes. Bayero Journal of Pure and Applied Sciences, 2(1): 52-57.

Kawo, A.H., Y.U Dabai, S.B. Manga and G.J. Garba (2012). Prevalence and public health implications of the bacterial load of environmental surfaces of some secondary schools in Sokoto, north-western Nigeria. International Research Journal of Microbiology, 3(5):186-190.

Kirby, W.M. and Bauer, A.W. (1996). Susceptibility testing: A standard single disc method. American Journal of Clinical Pathology, 45: 493-494.

Kumurya, A.S., Kawo, A.H. and Uba, A. (2010). Prevalence and in-vitro susceptibility studies of bacteria isolated from hospital patients presenting with otitis media in Kano, Nigeria. Biological and Environmental Sciences Journal for the Tropics, 7(1): 37-39.

Mbata, T.I. (2003). Isolation and characterization of micro-organisms found in public telephones. Proceedings of the $27^{\text {th }}$ conference of the Nigerian Society for Microbiology held at the University of Nigeria, Nsukka, November 30 to December 02, 2003. p2.
Mohammed, A., Kawo, A.H. and Yusha'u, M. (2006). Bacteriology of GSM cell phones. Journal of Research in Bioscience, 2(1): 47-50

Neubauer, G., Rooslim, K. N. and Wiart, J. (2005). Study on feasibility of epidemiological studies on health effects mobile telephone stations. Journal of Health and Population, 20(4): 200-210.

Nwadike, I. (2007). GSM made easy: Solution to every GSM problems. Sammy pet publishers, Lagos, Nigeria. p3.

Ogbini, A.O. and Omu, A.E. (1986). Nasal carriage rate of Staphylococcus aureus among hospital individuals. Nigerian Journal of Microbiology, 6(12): 41-46.

Ogbu, O. and Uneke, C.J. (2007). Potential parasite and bacterial transmission by paper currency in Nigeria. Journal of Environmental Health, 69(9): 54-60.

Tagoe, D.N., Gyande, V. and Ansa, E.V.O. (2011). Bacterial contamination of mobile phones: When your mobile phone could transmit more than just a cell. Webmed Microbiology, 2(10): 2294.

Uabol-Egbenni, P.O. (2003). Incidence of Staphylococcus aureus among healthy humans in Lagos and its environs. Nigerian Journal of Microbiology, 17(2):162-172.

Wieneke, A.A., Roberts, D. and Gilbert, R.J. (1993). Staphylococcal food poisoning in the United Kingdom (1969-1990). Journal of Epidemiology and Infectious Diseases, 110: 519-532.

World Health Organization (1980). Escherichia coli diarrhea. Bulletin of the World Health Organization, 58(1): 23-36.

Yusha'u, M., Bello, M. and Sule, H. (2010). Isolation of bacteria and fungi from personal and public cell phones: A case study of Bayero University, Kano (old campus). International Journal of Biomedical and Health Sciences, 6(1): 97-102.

Yusha'u, M., Hassan, A. and Kawo, A.H. (2008). Public health implications of the bacterial load of stethoscopes of some clinicians in Kano, Nigeria. Biological and Environmental Sciences Journal for the Tropics, 5(2): 196-199. 